Maslin, MA; Brierley, CM; (2015) The role of orbital forcing in the Early Middle Pleistocene Transition. Quaternary International 10.1016/i.quaint.2015.01.047.

\title{
Article
}

\section{The role of orbital forcing in the Early-Middle Pleistocene Transition}

\author{
Mark A. Maslin and Chris Brierley \\ Department of Geography, Pearson Building, University College London, London, \\ WC1E 6BT, UK
}

\begin{abstract}
The Early-Middle Pleistocene Transition (EMPT) is the term used to describe the prolongation and intensification of glacial-interglacial climate cycles that initiated after 900,000 years ago. During the transition glacial-interglacial cycles shift from lasting 41,000 years to an average of 100,000 years. The structure of these glacialinterglacial cycles shifts from smooth to more abrupt 'saw-toothed' like transitions. Despite eccentricity having by far the weakest influence on insolation received at the Earth's surface of any of the orbital parameters; it is often assumed to be the primary driver of the post-EMPT 100,000 years climate cycles because of the similarity in duration. The traditional solution to this is to call for a highly nonlinear response by the global climate system to eccentricity. This 'eccentricity myth' is due to an artefact of spectral analysis which means that the last 8 glacial-interglacial average out at about 100,000 years in length despite ranging from 80,000 to 120,000 years. With the realisation that eccentricity is not the major driving force a debate has emerged as to whether precession or obliquity controlled the timing of the most recent glacialinterglacial cycles. Some argue that post-EMPT deglaciations occurred every four or five precessional cycle while others argue it is every second or third obliquity cycle. We review these current theories and suggest that though phase-locking between orbital forcing and global ice volume may occur the chaotic nature of the climate system response means the relationship is not consistent through the last 900,000 years.
\end{abstract}

\section{Introduction}

The Early-Middle Pleistocene Transition (EMPT; previously known as the MidPleistocene Transition or Revolution; Berger and Jansen, 1994; Head et al. 2008) is the last major 'event' or transition in a secular trend towards more intensive global glaciation that characterizes the late Cenozoic (Zachos et al., 2001). The earliest recorded onset of significant regional glaciation during the Cenozoic was the widespread continental glaciation of Antarctica at about $34 \mathrm{Ma}$ (e.g., Zachos et al. 2001; Huber and Nof, 2006; Sijp et al., 2009). Perennial sea ice cover in the Arctic has occurred throughout the past $14 \mathrm{Ma}$ (Darby, 2008; Schepper et al., 2014). Glaciation in the Northern Hemisphere lagged behind, with the earliest recorded glaciation on Greenland occurring before about 6 Ma (e.g., Larsen et al., 1994; Thiede, et al., 2011). Schepper et al. (2014) have identified a number of key Pliocene 
glacial events which may have been global and occurred at 4.9-4.8 Ma, $4.0 \mathrm{Ma}$, $\sim 3.6 \mathrm{Ma}$ and $\sim 3.3 \mathrm{Ma}$. It is not until the Pliocene-Pleistocene transition that the longterm cooling trend culminates in the glaciation of Northern Europe and North America around 2.6 Ma (Maslin et al. 1998). The extent of glaciation did not evolve smoothly after this, but instead was characterized by periodic advances and retreats of ice sheets on a hemispherical scale - the 'glacial-interglacial cycles'.

The EMPT is the marked prolongation and intensification of glacial-interglacial climate cycles initiated sometime between 900 and $650 \mathrm{ka}$ (Figure 1). Before the EMPT, global climate conditions appear to have responded primarily to the obliquity orbital periodicity (Imbrie et al., 1992; Teidemann et al., 1994; Clark et al., 2006; Elderfield et al., 2012) through glacial-interglacial cycles with a mean periodicity of $\sim 41$ kyrs. After about 900 ka, starting with Marine Oxygen Isotope Stage (MOIS) 22, glacial-interglacial cycles start to occur with a longer duration and a marked increase in the amplitude of global ice volume variations (Elderfield et al., 2012; Rohling et al., 2014). The increase in the contrast between warm and cold periods may also be in part due to the extreme warmth of many of the post-EMPT interglacial periods as similar interglacial conditions can only be found at $\sim 1.1 \mathrm{Ma}, \sim 1.3 \mathrm{Ma}$ and before $\sim 2.2$ Ma. Figure 2 shows time-series analysis of the ODP 659 (Tropical East Atlantic ocean) benthic foraminifera oxygen isotope record spanning the EMPT (Mudelsee and Stattegger, 1997). The analysis suggests the EMPT was a two-step process with the first transition at about $900 \mathrm{ka}$, when there is a significant increase in global ice volume but the $41 \mathrm{kyr}$ climate response remains. This situation persists until the second step, about $700 \mathrm{ka}$, when the climate system finds a three-state solution and strong quasi-100 kyr climate cycles begin (Mudelsee and Stattegger, 1997). This is consistent with the more recent evidence from ODP Site 1123 in the Southern Pacific ocean, which shows a step like increase in ice volume during glacial periods starting at MOIS 22 at about 900 ka (Elderfield et al., 2012).

During the EMPT there seems to be a shift from a two stable climate state system to a system with three quasi-stable climate states (Figure 3). These three states roughly correspond to: 1) full interglacial conditions, 2) moderate glacial conditions such as MOIS 3 that are analogous to the glacial periods prior to the EMPT and 3) maximum glacial conditions for example MOIS 2, the Last Glacial Maximum (LGM). This has also added confused to the definition of the EMPT as many of the intermediate climate periods have been overlooked such as the weak interglacial at $\sim 740 \mathrm{ka}$, which does not have it own defined MOIS, or the double warm peaks during MOIS 15,13 , and 7.

\section{Climate Feedback mechanisms}

Central to understanding the EMPT is the appreciation that orbital variations do not directly cause global climate changes. Rather they induce small changes in the distribution of insolation across the globe that can in some instances be enhanced by strong positive or negative climate feedbacks and ultimately push the global climate into or out of a glacial period. The initial suggestion by Milankovitch (1949) was that glacial-interglacial cycles were regulated by summer insolation at about $65^{\circ} \mathrm{N}$; this was because he reasoned that for an ice sheet to expand additional ice had to survive each successive summer. The focus on the Northern Hemisphere is because the capacity for ice growth is much less in the Southern Hemisphere due to its smaller landmasses combined with the fact that Antarctica is already close to its ice storage limit. The conventional view of glaciation is that low summer insolation in the temperate North Hemisphere allows ice to survive the summer and thus build-up on the northern continents. As snow and ice accumulate the ambient environment is modified. This is primarily by an increase in albedo that reduces the absorption of 
incident solar radiation, and thus suppresses local temperatures. The cooling promotes the accumulation of more snow and ice and thus a further modification of the ambient environment, causing the so-called 'ice albedo' feedback. Other climate feedbacks such as changes in atmospheric circulation, surface and deep water circulation and the reduction in atmospheric greenhouse gases then play a role in driving the climate into a glacial period (e.g., Berger 1988; Li et al. 1998; Ruddiman, 2004; Brovkin et al., 2012). These feedbacks then operate in reverse when summer insolation starts to increase (Brovkin et al., 2012; Shakun et al., 2012).

For pre-EMPT it is suggested that there is a linear relationship between obliquity, heat transfer between latitudes and ice growth (Raymo \& Nisancioglu, 2003). Two major differences occur Post-EMPT. First, glacial periods become longer indicating that the ice sheets are able to survive orbitally-induced increases in summer insolation and having done so ice volume increases markedly during the following downturn in summer insolation creating more intense glacial periods such as the LGM. Second, the deglaciations are much more abrupt. In the case of the Termination I, the last deglaciation, the transition from glacial to interglacial state lasted only 5-6 kyr, even including the brief return to glacial conditions called the Younger Dryas period (see detailed references in Maslin et al. 2001). Hence an additional rapid climate feedback mechanism must be activated, namely sea level. Once ice sheets have expanded to their maximum and so impinge on the marine environment they become vulnerable. With an upturn in summer insolation in the North the ice sheet start to melt, this causes sea level to rise. The ice sheets adjacent to the coasts are under cut by rising sea levels accelerating their collapse, which in turns raises sea level. This sea-level feedback mechanism can be extremely rapid. This rapid deglaciation that has been postulated causes the saw-tooth climate signal, that is characteristic of glacial-interglacial cycles post-EMPR. However, this is a simplification, because though $80 \%$ of the ice sheet volume melts during this short period of time the remaining $20 \%$ or about 25 metres of global sea level does not fully disappear until 5,000 years later (Woodroffe and Webster, 2014), producing a kink in the rapid deglaciation curve (see Figure 3c).

Despite the pronounced change in Earth system response shown in palaeoclimatic records across the EMPT, the frequency and amplitude characteristics of the orbital parameters do not vary (Berger \& Loutre 1991, Berger et al. 1999). This indicates that the cause of change in response at the EMPT is internal rather than external to the global climate system.

\section{The 'eccentricity myth'}

The major problem with understanding the EMPT is how to interpret the ' $100 \mathrm{kyr}$ ' glacial-interglacial cycles and the role of eccentricity (Saltzman et al., 1984; Ghil 1994). There are two primary views (Maslin and Ridgwell, 2005). The first suggests that there is non-linear amplification in the climate system of the eccentricity signal; the second that the other factors drive global climate change and eccentricity rather acts as a pacing mechanism. This debate has not received the attention that it should amongst the wider palaeoclimatic community, and in many cases the last eight glacial-interglacial cycles are thought to be synomous with 'eccentricity forcing'. This view or 'myth' is fundamentally flawed and prevents many excellent palaeoclimatic records from being interpreted correctly. Below we reiterate why eccentricity cannot be the direct forcing of the $100 \mathrm{kyr}$ glacial-interglacial cycles.

Eccentricity has spectral peaks at 95 kyr, 125 kyr and 400 kyr (Hays, et al., 1976; Berger and Loutre, 1991). In contrast, the spectral analysis of benthic foraminiferal 
oxygen isotopes (Figure 4), which are a proxy for global ice volume and deep water temperature, consistently reveals a single peak that dominates the spectra lying very close to a period of $100 \mathrm{kyr}$ (Muller \& MacDonald 1997). If eccentricity were the primary cause of the $100 \mathrm{kyr}$ cycle then one would expect the global ice volume 100 kyr spectral peak to contain a double peak and that there would be at least some power at 400 kyr (Figure 4) (Ghil \& LeTreut 1981; Muller \& MacDonald 1997; Berger 1999). Ruddiman (2003) for instance clearly shows that the maximum of either an interglacial or glacial is missed by a simple 100,000 year filter.

This mismatch between the spectral signatures has led to the search for alternative drivers for the assumed 'pure' $100 \mathrm{kyr}$ response of the climate system, such as the orbital inclination driver proposed by Muller \& MacDonald (1997) or carbonatechemistry response time (Toggweiler, 2008). However, a strong $100 \mathrm{kyr}$ spectral peak in a truncated time series does not imply the presence of a $100 \mathrm{kyr}$ periodicity in the data (see Berger et al., 2005). Indeed, Ridgwell et al. (1999) showed that the observed spectral signature of ice volume can be reproduced by a simple saw-tooth pattern based on the long glaciation period followed by the short deglaciation (Fig 5). Here, the timing of the rapid deglaciation event is simply assumed to occur synchronous with every fourth or fifth precessional cycle. A similar saw tooth pattern can also be produced from obliquity using every second or third cycle, but the spectral analysis of this parameter matches the oxygen isotope record less precisely (Huybers and Wunsch, 2005). The length of the glacial-interglacial cycles is far from uniform in this analysis and the resultant spectral signature with a dominant ' $100 \mathrm{kyr}$ ' peak is thus in effect an artefact of spectral analysis. For example, Figure 1 shows that the time between deglaciations can vary from $120 \mathrm{kyr}$ to as little as $77 \mathrm{kyr}$ over the last $700 \mathrm{ka}$. Although the deglacial transitions are no more than quasi-periodic and do not recur at anything like a regular $100 \mathrm{kyr}$ interval, the resultant spectral analysis gives the appearance of a $\sim 100 \mathrm{kyr}$ periodicity present in the data. This is the 'eccentricity myth'. This observation has not stopped significant effort by the palaeoclimate community investigating the role of eccentricity in driving Pleistocene climate. For example, Lisieki (2010) uses a high Rayleigh number to justify that postEMPT cycles are synchronised to eccentricity - despite the fact that this is "not necessarily a good indicator of reliable synchronisation" Crucifix (2013). Rial et al. (2013) claim the $100 \mathrm{kyr}$ cycles emerge as a harmonic of the longer $413 \mathrm{kyr}$ eccentricity cycle exciting a natural resonance after nearly 5 million years.

If the post-EMPT '100 kyr' cycles are in effect an artefact of the spectral analysis of a truncated time series containing a dominant quasi-periodic glacial termination motif, then one must also question what we really mean by the EMPT. Although there is a clear visible change in the appearance of the ice volume variability revealed in proxy records (e.g. Fig. 1), the EMPT is typically defined through spectral analysis. The results of evolutive spectral analysis studies suggest step changes in the dominant frequency and mean ice volume associated with the EMPR, although not necessarily occurring synchronously (e.g., Mudelsee \& Schulz 1997; Mudelsee \& Stattegger 1997). The implications are of progressive steps to a new mode (oscillation) of the climate system, or a number of 'bifurcations' (Maslin 2004). However, it is less easy to see this elegant picture from the raw data.

As an example, we present a wavelet analysis of the global ice volume record of Rohling et al (2014) shown earlier (Figure 6; Torrence \& Compo, 1998; NCAR's Command Language, 2013). For instance, whereas significant power in the $100 \mathrm{kyr}$ band emerges at c. $900 \mathrm{ka}$ (MOIS 23 to 22), it then recedes between $\sim 800$ and $\sim 600$ ka (MOIS 19-16) and there is an interval of apparent obliquity-dominated (Figure 6). Even between $\sim 600 \mathrm{ka}$ (MIOS 16) and present, the variability in ice volume at times contains significant power in the obliquity and precession bands (as seen in the pre- 
EMPT $41 \mathrm{kyr}$ 'world'). It is also clear the significant power is not strictly confined to $100 \mathrm{kyr}$, but spans 80-125 kyr. However, sufficient quasi-periodic recurrence occurred in the past 600 or 900 kyr to allow a strong 100 kyr peak emerge in a spectral analysis (see Figure 4).

\section{Obliquity versus Precession debate}

A debate has emerged over whether precession or obliquity controlled the timing of the most recent glacial-interglacial cycles, in light of the observation that eccentricity did not. Huybers and Wunsch (2005) and Huybers (2007; 2009) argue that postEMPT deglaciations occur every second or third obliquity cycle. Alternatively, Ridgwell et al. (1999) and Maslin and Ridgwell (2005) argue that deglaciation occurred every four or five precessional cycle.

Prior to the EMPT the climate system is dominated by obliquity, the so-called $41 \mathrm{kyr}$ world. Raymo \& Nisancioglu (2003) suggest the climate system was sensitive to obliquity-forced latitudinal insolation gradients, which exert a strong control on summer atmospheric heat transport. Although the insolation curves for the Northern Hemisphere are dominated through time by precession, the insolation gradient between high and low latitude is dominated by obliquity (Berger et al., 2010). This obliquity-driven insolation gradient must therefore be the prime control on glacialinterglacial cycles prior to the EMPT. Raymo \& Nisancioglu (2003) suggest that differential heating between high and low latitudes in summer exerts a dominant control on global climate through its impact on the atmospheric meridional flux of energy, moisture and latent heat. As the majority of heat transport between $30^{\circ}$ and $70^{\circ} \mathrm{N}$ is by the atmosphere, a linear relationship between obliquity, northward heat transport and glacial-interglacial cycles can be envisioned. When this summer heat transport was low the ice sheets could build-up, and when heat transport increased the ice sheets correspondingly shrunk. This is a bi-modal system responding approximately linearly to insolation gradients. The pollen-based reconstruction of the latitudinal temperature gradient by Davis \& Brewer (2008) not only supports this suggestion, but also implies a greater sensitivity to insolation gradients than initially expected.

Alternate explanations for the role of obliquity include it controlling Antarctic snow accumulation (Lee \& Poulsen, 2008) and the fact that obliquity controls annual mean insolation over all latitudes (Loutre et al., 2004). The limited size of continental ice sheets meant they were less susceptible to rapid deglaciation due to sea level rise, resulting in the relatively gradual deglaciations observed at this time. The spectral signature of pre-EMPT ice volume therefore shows a dominance of obliquity over precession. It has also been suggested the dominance of obliquity is an artefact arising as the precessional signal is 'cancelled out' (Raymo and Huybers, 2008). This is because precession is anti-phase between the Northern and Southern Hemispheres while obliquity changes are in phase. If the temperature and sea level changes between the two Hemispheres driven by precession were approximately the same, they would be out of phase and hence cancel out. One could envisage Northern Hemisphere ice sheets varying with precession leading to a benthic foraminifera $\delta^{18} \mathrm{O}$ response that is countered by an equal and opposite response from the Southern Hemisphere ice sheets (Raymo et al., 2006). This suggestion is perhaps refuted by recent sea level reconstructions (Figures 1 \& 6; Rohling et al. 2014; Elderfield et al., 2012). The Antarctic ice volume variations required to disguise precessional forcing of benthic $\delta^{18} \mathrm{O}$ and sea level are different, because of differing isotopic fractionation of the Northern and Southern Hemisphere ice-sheets. For example during the last glacial, the Laurentide ice sheet had an average $\delta^{18} \mathrm{O}$ of -28 
per mil to -34 per mil, whereas the Antarctic was between -40 per mil and -60 per mil (Maslin and Swann, 2006). Moreover reconstruction of the waxing and waning of early Pleistocene glacial outwash plains in North America has been shown to be obliquity paced, strongly arguing against a precession controlled Laurentide ice sheet during this time (Naafs et al., 2012).

Huybers and Wunsch (2005) and Huybers (2007; 2009) argued that the obliquity mechanism is intrinsic to the climate system and must continue after the EMPT. They suggested that post-EMPT deglaciations occur every second or third obliquity cycle. The problem that they encountered is the timing of each of the major deglaciations, since the EMPT, occurs on very different parts of the rising arm of the obliquity curve. They also encounter the Termination III problem as this occurs as obliquity is dropping, so they opted to define this deglaciation not at $240 \mathrm{ka}$ but at the second rise in oxygen isotopes at $210 \mathrm{ka}$. What is clear from both oxygen isotope and global sea level records is that the timing of deglaciations since the start of the EMPT all occur on the rising limb of the precessional curve (Figure 5) when there is the greatest rate of change in precessional forcing (Maslin et al., 2005).

Raymo (1997) suggested that the episodic occurrence of precessionally driven unusually low maxima in Northern Hemisphere summer insolation is the critical factor controlling subsequent deglaciation. In this model, glacial termination only occurs when the climate system has been predisposed by excessive ice sheet growth by a previous low maxima in Northern Hemisphere summer insolation to some critical maximum degree of glaciation (see Figure 4). Of course one such time is the LGM. This critical threshold might reflect the sinking of the underlying bedrock to an extent sufficient to allow full activation of additional and catastrophic mechanisms of ice sheet collapse once the ice sheet starts to initially retreat under an unfavourable combined insolation and $\mathrm{CO}_{2}$ radiative forcing regime (e.g., Imbrie et al., 1993; Clark and Pollard, 1998; Ganopolski and 2011). In other words, precession driven summer minima push the glacial climate system too far and it collapses all the way back into an interglacial period (Tziperman and Gildor, 2003). Although eccentricity determines the envelope of precessional amplitude it is ultimately whether the insolation minimum occurs on the fourth or fifth precessional cycle that determines when overextension of the ice sheets can occur which results ultimately in the rapid deglaciation (Ridgwell et al. 1999; Maslin and Ridgwell, 2005). This theoretical construction is supported by the sea level evidence from the most recent deglaciation. The loss of ice equivalent to 90-100 metres of global sea level occurred very rapidly while the major ice sheets were vulnerable to the effects of rising sea level. Once the continental ice sheets had retreat sufficiently not to be under cut by rising sea level the remaining 20-25 metres of equivalent sea level took nearly 5,000 years to melt. The precessional threshold model is alsosupport by recent ice sheet modelling work, which shows that precessional forcing is the dominant control on global ice volume (Abe-Ouchi et al. 2013).

It may be that such an argument is itself unnecessary and that both obliquity and precession contribute to the $100 \mathrm{kyr}$ cycles seen after the EMPT. Huybers (2011), for example, used a novel statistical approach to find robust influences with both. Using concepts of general synchronisation from the discipline of dynamical systems theory, De Saedeleer et al. (2013) reach a similar conclusion. Crucifix (2013) goes further and demonstrates the climate system forced by the full orbital solution is sensitive to stochastic events to such an extent that the question of obliquity or precession may be ill posed. This instability will lead to quantum skips of insolation cycles - effectively at random (Crucifix, 2013). 


\section{Discussion}

The EMPT could be thought of not as a transition to a new mode of glacialinterglacial cycles per se, but simply the point at which a more intense and prolonged glacial state and associated subsequent rapid deglaciation becomes possible. An important point in this view is that whereas from the EMPT onwards it may be possible for the climate system to achieve this new glacial climate solution, it need not do so each time. The success or failure to achieve this state would be determined by factors such as the exact details of insolation regime and carbon cycling. One would also expect an increasing probability of a '100 kyr' motif occurring with time, as the long-term late Cenozoic cooling $/ \mathrm{CO}_{2}$ trend presumably continues.

A number of different theories have been forwarded as to why after the EMPT ice sheets were able to survive longer and became increasing vulnerable to catastrophic collapse and the resultant rapid deglaciation. It has been suggested that long term cooling through the Cenozoic instigated a threshold, which allowed the ice sheets to become large enough to ignore the $41 \mathrm{kyr}$ orbital forcing and to survive between 80 and 100 ka (Abe-Ouchi 1996; Raymo et al. 1997). In one version of this, Gildor \& Tziperman (2000) and Tziperman \& Gildor (2003) suggest that long term cooling of the deep ocean during the Pleistocene alters the relationship between atmospheric temperature and accumulation rates of snow on continental ice sheets and the growth of sea ice. They envision this alteration causing more extensive global coverage of sea ice. The climate could then be affected by a so-called sea-ice switch which would produce the rapid asymmetric deglaciation observed after the EMPT. Alternatively, Northern Hemisphere ice sheets impinging into the ocean may be stable to some (Gomez et al., 2010), but not all forcing conditions.

It has been suggested that the critical size of the Northern Hemisphere ice sheets may have been influenced by changing levels of greenhouse gases (Clark et al., 2006; Crowley and Hyde, 2008; DeConto et al., 2008). The atmospheric carbon dioxide reconstruction by Hönisch et al. (2009) shows significant changes at the EMPT and the Mid-Brunhes Event (MBE) see Figure 7. Though the data is sparse it seems to indicate a drop in both the interglacial level of carbon dioxide from 290 ppm to $~ 260 \mathrm{ppm}$ and the glacial level from $220 \mathrm{ppm}$ to $180 \mathrm{ppm}$. At the MBE the glacial level remains the same but the interglacial level rises to it pre-EMPT level of 290 ppm (Hönisch et al., 2009). Hence the cooling trend through the EMPT could have been driven by the observed reduced concentration of greenhouse gases in the atmosphere. This secular decline in the concentration of $\mathrm{CO}_{2}$ in the atmosphere could have brought the global climate to a threshold, allowing it to respond nonlinearly to orbital forcing thereafter (Mudelsee and Stattegger 1997; Mudelsee and Schultz 1997; Raymo et al. 1997; Berger et al. 1999). Saltzman (2001) takes this further and proposes that in crossing this threshold ('bifurcation') an internal instability arises in the global carbon cycle that leads to the activation of an internal 100 kyr oscillator. Such a threshold occurs in the model used by Crowley and Hyde (2008), who state that $\sim 100 \mathrm{kyr}$ power is "embedded in the physics of the coupled climate/ice-sheet system". In this view, orbital forcing plays only a very minor phaselocking role. If atmospheric carbon dioxide and not Northern Hemisphere ice volume is the primary driving force of the $\sim 100 \mathrm{kyr}$ glacial-interglacial cycles (as in the suggestion of Toggweiler, 2008), then an interpretation consistent with palaeoclimatic proxies suggests that eccentricity, atmospheric carbon dioxide, Vostok (Antarctica) air temperatures and deep water temperatures are in phase; whereas ice volume lags these other variables, as originally suggested by Shackleton (2000). In this case the EMPT could represent a change in the internal response of the global carbon cycle to orbital forcing. This is consistent with ice sheet modelling results, 
which show the importance of atmospheric carbon dioxide levels in the initiation and maintenance of the Eastern Antarctic (Pollard and DeConto, 2009) and Greenland (Lunt et al. 2008) ice sheets. Crowley and Hyde (2008) even found a further threshold, after which Eurasia would start to maintain large ice-sheets. They suggested such a threshold would have been crossed in the geological record, had mankind not altered the climate system's trajectory.

\section{Conclusion}

There is clear evidence for both a prolongation and intensification of glacialinterglacial climate cycles during the Early-Middle Pleistocene Transition (EMPT). We suggest the structure of glacial-interglacial cycles shifts from a smooth sinusoidal structure to a tripartite system (Figure 3) whose spectral signature is dominated by the large and rapid deglaciations. We suggest that previous explanations of a nonlinear response to eccentricity or a linear response to either obliquity or precession are too simplistic. It is clear that prior to the EMPT the timing of glaciations and deglaciations is linked to obliquity and after the EMPT they are also influenced by precession. The intensification of the glacial periods, however, are linked to the ability of the climate system to ignore successive upturns in obliquity, hence the glacial cycles last on average two or three obliquity cycles before deglaciation occurs. This also represents an increased dominance of the Northern hemisphere in driving glacial-interglacial cycles. Prior to the EMPT the obliquity forcing would have been in the same direction in both Hemispheres producing a re-enforcement into or out of a glacial period. Post EMPT precession provides the deglaciation timing but its influence on the Hemispheres would have been in opposition. We speculate that the EMPT was may be due to a changing internal response of the global carbon cycle to orbital forcing, which allowed increased ice sheet growth in the Northern Hemisphere which provided enough local climate feedbacks for the increased heat transport northward driven by obliquity to be ignored. It seems that the climate system is a stochastic system, which is modulated by orbital forcing. However the ever changing relationship between the different orbital parameters and their relationship with the internal climate feedbacks means that there is no consistent phase lock-in (Huybers, 2011; De Saedeleer et al., 2013; Crucifix, 2013). What does seem to be critical post-EMPT is the occasional generation of 'full' glacial conditions which make the whole system very unstable allowing the climate to rebound out suddenly in to full interglacial condition.

\section{Acknowledgements}

We would like to thank the UCL Department of Geography Drawing Office in help in preparing the diagrams for this paper.

Wavelet software was provided by C. Torrence and G. Compo.

This is available at the URL: http://paos.colorado.edu/research/wavelets/ although we use the implementation in NCL. 


\section{Figure Captions}

\section{Figure 1.}

A) Comparison of the benthic foraminiferal oxygen isotope curve from ODP Site 659 (Tiedemann et al. 1994) with the timing between Terminations (Raymo, 1997; Tiedemann et al., 1994). B) Comparison of two alternate records of global sea level. Black: the marginal sea reconstruction of Rohling et al (2014) for non-sapropel layers (the dotted portions correspond to the median estimates from linear interpolation and are included for aesthetic reasons). We convert to Global Eustatic sea level, by applying a multiplicative factor of 1.23 chosen for the most recent glacial cycle. Red: Eustatic sea level determined from a deconvolution of combined benthic foraminifera $\delta^{18} \mathrm{O}$ and $\mathrm{Mg} / \mathrm{Ca}$ temperature measurement from the South-west Pacific (Elderfield et al, 2012). We show the mode and 5-95\% range from the probabilistic re-interpretaion by Rohling et al. (2014).

\section{Figure 2.}

Statistical analysis of the mid-Pleistocene revolution by Mudelsee \& Stattegger (1997) demonstrating a delay of $200 \mathrm{kyr}$ between a significant increase in global ice volume and the start of the $100 \mathrm{kyr}$ glacial-interglacial cycles. They show that global ice volume increased significantly between 940 and 890 ka. Whereas evolutionary spectral analysis reveals an abrupt increase of 100-ka cycle amplitude much later at approximately $650 \mathrm{ka}$. Probability density function (PDF) exhibits a bifurcation behaviour at approximately $725 \mathrm{ka}$. This suggests that the EMPT moved from two state system, full glacial period and full interglacial period to a more complicated system with multiple states as suggested by Paillard (1998) and Saltzman (2001) and illustrated in Figure 3.

\section{Figure 3.}

Cartoon illustrating the changes in glacial-interglacial cycles before $(A)$ and after the EMPT (B and $\mathrm{C})$. Note that post-EMPT the glacial-interglacial cycles are not simple saw-toothed feature (B) but rather a tripartite system (C) which spends relatively short periods of time in either full glacial or interglacial conditions. MOIS = Marine Oxygen Isotope Stage.

\section{Figure 4.}

a) general properties of benthic foraminifera oxygen isotope records from the Pacific (OJsox96) and the Atlantic (Imb84) for the last $700 \mathrm{kyr}$ (adapted from Berger et al. 1996). b) fourier spectra of the two series, showing not the strong single peak at $\sim 100 \mathrm{kyr}$, but the dominant orbital frequencies of 19, 23, 41, 95, 125 and $400 \mathrm{kyr}$.

\section{Figure 5.}

a) SPECMAP stacked $\delta^{18} \mathrm{O}$ composite showing marine oxygen isotopes stage with spectral analysis b) insolation for June $21^{\text {st }} 65^{\circ} \mathrm{N}$ showing the quasi-periodic insolation maxima of unusually low strength (shown by arrows) preceding glacialinterglacial terminations by one precessional cycle in each case, with spectral analysis and c) sawtooth artificial ice volume signal with spectral analysis with spectral analysis (adapted from Ridgwell et al. 1999). 


\section{Figure 6.}

Wavelet power shown in the eustatic sea level reconstruction of Rohling et al. (2014). The analysis has been performed on the continuous median estimates, whose interpolation over sapropel layers will lead to some errors at higher frequencies. Cross-hatching indicates regions influenced by the end of the reconstruction, whilst stippled regions are statistically significant at the 5\% confidence level. Significant power in the $100 \mathrm{kyr}$ band emerges at c. $900 \mathrm{ka}$, then recedes between $\sim 800$ and $\sim 600 \mathrm{ka}$ and then re-merges after $600 \mathrm{ka}$. The interval between $\sim 800-\sim 60 \mathrm{ka}$ is apparently obliquity-dominated. After $\sim 600 \mathrm{ka}$ the variability in eustatic sea level contains significant power in the obliquity and precession bands. It is also clear the significant power is not strictly confined to $100 \mathrm{kyr}$, but spans $80-125 \mathrm{kyr}$.

\section{Figure 7.}

Surface ocean aqueous $\mathrm{PCO}_{2}$ (dots with errors bars) calculated as a function of $\mathrm{pH}$, alkalinity, SST, and salinity by Hönisch et al. (2009) compared with the ice core record of atmospheric $\mathrm{PCO}_{2}$ (solid line). Average glacial and interglacial carbon doixide levels are indictaed by horizontal lines (this study). Note the changes at the Early-Middle Pleistocene Transition (EMPT) and the Mid Brunhes Event (MBE).

\section{References}

Abe-Ouchi, A. 1996. Quaternary transition: A bifurcation in forced ice sheet oscillations? Eos Transactions AGU, 77 (46), Fall Meeting Supplement, F415.

Abe-Ouchi et al., 2013

Berger, A. 1988. Milankovitch Theory of Climate. Review of Geophysics, 26(4), 624657.

Berger, A. \& Loutre, M. F. 1991. Insolation values for the climate of the last 10 million years. Quaternary Science Reviews, 10, 297-317.

Berger, A. \& Loutre, M. F. 1996. Modelling the climate response to the astronomical and CO2 forcing. Comptes Rendus de l'Academie des Sciences de Paris, 323, series Ila, 1-16.

Berger, A., Li, X., Loutre, MF. 1999. Modelling northern hemisphere ice volume over the last $3 \mathrm{Ma}$. Quaternary Science Reviews, 18, 1-11.

Berger, A., J.L. Melice, M.F. Loutre (2005) On the origin of the 100-kyr cycles in the astronomical forcing.

Paleoceanography, 20, PA4019http://dx.doi.org/10.1029/2005PA001173

Berger A, Loutre MF, Yin QZ (2010) Total irradiation during any time interval of the year using elliptic integrals. Quat Sci Rev 29:1968-1982.

Berger, W. H. 1999. The 100-kyr ice-age cycle: internal oscillation or inclinational forcing? International Journal Earth Science, 88, 305-316.

Berger, W. H. \& Jansen, E. 1994. Mid-Pleistocene climate shift: the Nansen connection. In: Johannessen et al. (eds). The polar oceans and their role in shaping the global environment. AGU Geophysical Monograph 85, 295-311.

Berger, W. H., Bickert, T., Schmidt, H. \& Wefer, G. 1993. Quaternary oxygen isotope record of pelagic foraminiferas: Site 806, Ontong Java Plateau. In: Berger, W.H., Kroenke, L.W., Mayer, L.A. et al., Procedings ODP, Scientific Results, 130, College Station, TX (Ocean Drilling Program), 381-395.

Berger, W. H. \& Wefer G. 1996. Expeditions into the Past: Paleoceanographic studies in the South Atlantic, In: Wefer et al. (editors) The South Atlantic: present and past ciculation, Spinger-Verlag, Berlin, 363-410.

Berger, W. H. \& Wefer, G. 2003. On the dynamics of the ice ages: Stage-11 paradox, mid-Brunhes climate shift and 100-ky cycle. In: Droxler, A., Poore, R. \& 
Burckle, L. (eds) Earth's Climate and Orbital Eccentricity: The Marine Isotope Stage 11 Question, Geophysical Monograph Series 137, 41-59.

Brovkin, V. , Ganopolski, A., Archer, D., and Munhoven G. (2012) Glacial $\mathrm{CO}_{2}$ cycle as a succession of key physical and biogeochemical processes. Clim. Past, 8, 251-264,

Clark, P. \& Pollard, D. 1998. Origin of the middle Pleistocene transition by ice sheet erosion of regolith. Paleoceanography, 13, 1-9.

Clark, P.U., Archer, D., Pollard, D., Blum, J.D., Rial, J.A., Brovkin, V., Mix, A.C., et al., 2006. The middle Pleistocene transition: characteristics, mechanisms, and implications for long-term changes in atmospheric pCO2. Quaternary Science Reviews 25 (23-24), 3150-3184. doi: 10.1016/j.quascirev.2006.07.008

Crowley, T. J., and W. T. Hyde (2008), Transient nature of late Pleistocene climate variability, Nature, 456(7219), 226-230, doi:10.1038/nature07365.

Crucifix, M., 2013. Why could ice ages be unpredictable?, Climate of the Past 9 2253--2267 doi:10.5194/cp-9-2253-2013

Darby, D. A. (2008), Arctic perennial ice cover over the last 14 million years, Paleoceanogr., 23(1), PA1S07, doi:10.1029/2007PA001479.

DeConto, R. M., D. Pollard, P. A. Wilson, H. Pälike, C. H. Lear, and M. Pagani (2008), Thresholds for Cenozoic bipolar glaciation, Nature, 455(7213), 652656, doi:10.1038/nature07337.

Denton, G. H., 2000. Does asymmetric thermohaline-ice-sheet oscillator drive 100,000-yr cycles, Journal of Quaternary Science, 15, 301-318.

Droxler, A., Poore, R. \& Burckle, L. 2003. Earth's Climate and Orbital Eccentricity: The Marine Isotope Stage 11 Question, Geophysical Monograph Series 137, p.240.

EPICA community members. 2004. Eight glacial cycles from an Antarctic ice core. Nature, 429, 623-628.

Farley, K. \& Patterson, D. B. 1995. A 100 kyr periodicity in the flux of extraterrestrial $3 \mathrm{He}$ to the sea floor. Nature, 378, 600-603.

Ganopolski, A, and Calov R. (2011) The role of orbital forcing, carbon dioxide and regolith in 100 kyr cycles. Clim. Past, 7, 1415-1425, doi:10.5194/cp-7-14152011

Ghil, M. (1994) Cryothermodynamics: the chaotic dynamics of paleoclimate. Physica D: Nonlinear Phenomena, 77, 1-3, 130-159.

Gildor, H. \& Triperman, E. 2000. Sea ice as the glacial cycles climate switch, Paleoceanography, 15, 605-615.

Hönisch, B., N.G. Hemming, D. Archer, M. Siddall, J. McManus (2009) Atmospheric Carbon Dioxide Concentration Across the Mid-Pleistocene Transition. Science, 324, 1551-1554 DOI: $10.1126 /$ science. 1171477.

Huber, M., and Nof, D., 2006, The ocean circulation in the southern hemisphere and its climatic impacts in the Eocene: Palaeogeography, Palaeoclimatology, Palaeoecology, v. 231, p. 9-28, doi:10.1016/j.palaeo.2005.07.037.

Hays, J.D., Imbrie, J. \& Shackleton, N.J. 1976. Variations in the Earth's orbit: Pacemaker of the Ice Ages. Science, 194, 1121-1132.

Head, M.J., Pillans, B., and Farquhar, S., 2008. The Early-Middle Pleistocene Transition: characterization and proposed guide for the defining boundary. Episodes 31(2): 255-259.

Huybers, P. J. (2011), Combined obliquity and precession pacing of late Pleistocene deglaciations, Nature, 480(7376), 229-232, doi:10.1038/nature10626.

Imbrie, J., Berger, A., Boyle, E. A., Clemens, S. C., Duffy, A., Howard, W. A., Kukla, G., Kutzbach, J., Martinson, D. G., Mclntyre, A., Mix, A. C., Molfino, B., Morley, J. J., Peterson, L. C., Pisias, N. G., Prell, W. G., Raymo, M. E., Shackleton, N. 
J. \& Toggweiler, J. R. 1993. On the structure and origin of major glaciation cycles. 2. The 100,000 year cycle. Paleoceanography 8, 699-735.

Imbrie, J., Boyle, E., Clemens, S., Duffy, A., Howard, W., Kukla, G., Kutzbach, J., Martinson, D., Mclntyre, A., Mix, A., Molfino, B., Morley, J., Peterson, L., Pisias, N., Prell, W., Raymo, M., Shackleton, N. \& Toggweiler, J. R. 1992. One the structure and origin of major glaciation cycles. 1. Linear responses to Milankovitch forcing. Paleoceanography, 7, 701-738.

Kennett, J., Cannariato, K.G., Hendy, I.L. \& Behl, R.J. 2003. Methane hydrates in Quaternary climate change: The clathrate gun hypothesis: American Geophysical Union, p.216.

Kortenkamp, S. J., \& Dermott, S. F. 1998. A 100,000 year periodicity in the accretion rate of interplanetary dust. Science, 280, 874-876.

Larsen, H. C., A. D. Saunders, P. D. Clift, J. Begét, W. Wei, S. Spezzaferri, J. Ali, H. Cambray, A. Demant, G. Fitton, M. S. Fram, K. Fukuma, J. Gieskes, M. A. Holmes, J. Hunt, C. Lacasse, L. M. Larsen, H. Lykke-Andersen, A. Meltser, M. L. Morrison, N. Nemoto, N. Okay, S. Saito, C. Sinton, R. Stax, T. L. Vallier, D. Vandamme, and R. Werner, 1994. Seven Million Years of Glaciation in Greenland. Science, 264, 5161, 952-955.

Laskar, J. 1990. The chaotic motion of the solar system: A numerical estimate of the chaotic zones. Icarus, 88, 266-291.

Lea, D.W., Pak, D., \& Spero, H. 2000. Climate impact of late Quaternary equatorial sea surface temperature variations. Science, 289, 1719-1724.

Lee, S.-Y., and C. J. Poulsen (2009), Obliquity and precessional forcing of continental snow fall and melt: implications for orbital forcing of Pleistocene ice ages, Quaternary Science Reviews.

Li, X.S., Bergerm A., \& M.F. Loutre, 1998. $\mathrm{CO}_{2}$ and Northern Hemisphere ice volume variations over the middle and late Quaternary. Climate Dynamic, 14, 537-544.

Loutre, M.-F., D. Paillard, F. Vimeux, and E. Cortijo (2004), Does mean annual insolation have the potential to change the climate? Earth and Planetary Science Letters, 221(1-4), 1-14, doi:10.1016/S0012-821X(04)00108-6.

Maasch, K. A. \& Saltzman, B. 1990. A low-order dynamical model of global climatic variability over the full Pleistocene. Journal of Geophysical Research, 95, 19551963.

Maslin, M.A. (2004) Ecological verses Climatic Thresholds. Science, 306, 2197-8.

Maslin M.A., Li, X. S., Loutre M. F., \& Berger A. 1998. The contribution of orbital forcing to the progressive intensification of Northern Hemisphere Glaciation. Quaternary Science Reviews, 17, 411-426.

Maslin, M.A., Seidov, D. \& Lowe, J. 2001. Synthesis of the nature and causes of sudden climate transitions during the Quaternary In: Seidov, D. Haupt B., \& Maslin, M. A. eds) The oceans and rapid climate change: past, present and future AGU Geophysical Monograph Series 126, 9-52.

Maslin, M.A., and G., Swann, 2006. Isotopes in Marine Sediments: In Isotopes in Palaeoenvironmnetal Research (M. Leng editor) Springer, Dordrecht, The Netherlands, 227-290.

Maslin, M.A. and A. Ridgewell, 2005. "Mid-Pleistocene Revolution and the eccentricity myth" Special Publication of the Geological Society of London, 247, 19-34.

Milankovitch, M.M. 1949. Kanon der Erdbestrahlung und seine Anwendung auf das Eiszeitenproblem. Royal Serbian Sciences, Spec. pub. 132, Section of Mathematical and Natural Sciences, 33, Belgrade, p.633 (Canon of Insolation and the Ice Age Problem, English translation by Israel Program for Scientific Translation and published for the U.S. Department of Commerce and the National Science Foundation, Washington D.C., 1969). 
Mudelsee, M. \& Schulz, M. 1997. The Mid-Pleistocene climate transition: onset of 100 ka cycle lags ice volume build up by $280 \mathrm{ka}$. Earth and Planetary Science Letters, 151, 117-123.

Mudelsee, M. \& Stattegger, K. 1997. Exploring the structure of the mid-Pleistocene revolution with advance methods of time-series analysis. Geologische Rundschau, 86, 499-511.

Muller, R. A. \& MacDonald, G. J. 1997. Glacial cycles and astronomical forcing. Science 277, 215-218.

The NCAR Command Language (Version 6.1.2) [Software]. (2013). Boulder, Colorado: UCAR/NCAR/CISL/VETS. http://dx.doi.org/10.5065/D6WD3XH5

Paillard, D. 1998. The timing of Pleistocene glaciations from a simple multiple-state climate model. Nature, 391, 378-381.

Paul, A. \& W. H. Berger W. H. 1999. Climate cycles and climate transitions as a response to astronomical and $\mathrm{CO}_{2}$ forcings. In Harff, J.,Lemke, W. \& Stattegger, K. (eds) Computerized modeling of sedimentary Systems. SpringerVerlag, Berlin, Heidelberg, 223-245.

Petit, J. R., Jouzel, J., Raynaud, D., Barkov, N., Barnola, J., Basile, I., Bender, M., Chappellaz, J., Davis, M., Delaygue, G., Delmotte, M., Kotlyakov, V., Legrand, M., Lipenkov, V., Lorius, C., Pepin, L., Ritz, C., Saltzman, E. \& Stievenard, M. 1999. Climate and atmospheric history of the Past 420000 years from the Vostok Ice Core, Antarctica. Nature, 399, 429-436.

Pisias N.G. \& Mooore, T.C. 1981. The evolution of Pleistocene climate: a time series approach. Earth Planet, 52, 450-458.

Prell, W. L. 1984. Covariance patterns of foraminifera $d^{18} \mathrm{O}$ : An evaluation of Pliocene ice-volume changes near 3.2 million years ago. Science, 226, 692694.

Raymo, M. E. 1997. The timing of major climate terminations. Paleoceanography, 12, 577-585.

Raymo, M. E., and P. J. Huybers (2008), Unlocking the mysteries of the ice ages, Nature, 451(7176), 284-285, doi:10.1038/nature06589.

Raymo, M. E., L. E. Lisiecki, and K. H. Nisancioglu (2006), Plio-Pleistocene ice volume, Antarctic climate, and the global $\delta 180$ record, Science, 313(5786), 492-495, doi:10.1126/science.1123296.

Raymo, M. E. \& Nisancioglu, K. 2003. The 41 kyr world: Milankovitch's other unsolved mystery, Paleoceanography, 18, 1, 1011, DOI: 10.1029/2002PA000791.

Raymo, M., Oppo, D. \& Curry, W. 1997. The mid-Pleistocene climate transition: A deep sea carbon isotope perspective. Paleoceanography, 12, 546-559.

Ridgwell, A. \& Watson, A. 2002. Feedback between aeolian dust, climate and atmospheric $\mathrm{CO}_{2}$ in glacial times, Paleoceanography, 17(4), 1059, DOI 10.1029/2001PA000729.

Ridgwell, A., Watson, A. \& Raymo, M. 1999. Is the spectral signature of the $100 \mathrm{kyr}$ glacial cycle consistent with a Milankovitch origin. Paleoceanography, 14, 437440.

Ridgwell, A. J., Watson, A. J., Maslin, M. A. \& Kaplan, J. O. 2003. Implications of coral reef build-up for the controls on atmospheric $\mathrm{CO}_{2}$ since the Last Glacial Maximum. Palaeoceanography, 18(4), 1083 10.1029/2003PA000893.

Ruddiman, W. F. 2003. Orbital insolation, ice volume, and greenhouse gases. Quaternary Science Reviews, 22, 1597-1629.

Ruddiman, W. F. 2004. The role of greenhouse gases in orbital-scale climatic changes. EOS, 285, 1, 6-7.

Ruddiman, W.F. \& Raymo, M.E. 2003. A methane-based time scale for Vostok ice. Quaternary Science Reviews, 22, 141-155. 
De Saedeleer, B., M. Crucifix, and S. Wieczorek (2012), Is the astronomical forcing a reliable and unique pacemaker for climate? A conceptual model study, Climate Dynam., 40(1-2), 273-294, doi:10.1007/s00382-012-1316-1.

Saltzman, B. 2001. Dynamical paleoclimatology : generalized theory of global climate change. Academic Press, San Diego, p.320.

Saltzman, B. \& Maasch, K. A. 1988. Carbon cycle instability as a cause of the late Pleistocene ice age oscillations: modeling the asymmetric response. Global Biogeochemical Cycles, 2, 177--185.

Saltzman, B., A. Sutera, and A. R. Hansen (1984), Earth-orbital eccentricity variations and climatic change, in Milankovitch and Climate, Part 2, edited by A. Berger, pp. 615-636, D. Reidel, Norwell, Mass.

Saltzman, B., \& Maasch, K. A. 1991. A first-order global model of late Cenozoic climatic change. Climate Dynamics, 5, 201-210.

Saltzman, B., Maasch, K.A. \& Verbitsky, M. Ya. 1993. Possible effects of anthropogenically increased $\mathrm{CO}_{2}$ on the dynamics of climate: Implications for ice age cycles. Geophysical Research Letters, 20, 1051-1054.

Schepper, S.D., P.L. Gibbard, U. Salzmann, J. Ehlers, 2014. A global synthesis of the marine and terrestrial evidence for glaciation during the Pliocene Epoch, Earth-Science Reviews, 135, 83-102

Shackleton, N.J. 2000. The 100,000 year Ice Age cycle identified and found to lag temperature, carbon dioxide and orbital eccentricity. Science, 289, 1989-1902.

Shackleton, N.J., Imbrie, J. \& Pisias, N.G. 1988. The evolution of oceanic oxygenisotope variability in the North Atlantic over the past 3 million years. Philosophical Transactions of the Royal Society of London, B, 318, 679-686.

Shakun, J. D. et al. Global warming preceded by increasing carbon dioxide concentrations during the last deglaciation. Nature 484, 49, doi:10.1038/nature10915 (2012).

Sigman, D. \& Boyle, E. 2000. Glacial/interglacial variations in atmospheric carbon dioxide. Nature, 407, 859 - 869.

Sijp, W.P., England, M.H., and Toggweiler, J.R., 2009, Effect of ocean gateway changes under greenhouse warmth: Journal of Climate, 22, 6639-6652, doi:10.1175/2009JCLI3003.1.

Thiede, JC Jessen, P Knutz, A Kuijpers, N Mikkelsen, N Norgaard-Pedersen, and R Spielhagen (2011) Millions of Years of Greenland Ice Sheet History Recorded in Ocean Sediments. Polarforschung. 80(3):141-159.

Tiedemann, R., Sarnthein, M. \& Shackleton, N.J. 1994. Astronomic timescale for the Pliocene Atlantic $d^{18} \mathrm{O}$ and dust flux records of ODP Site 659. Paleoceanography, 9, 619-638.

Timmermann, A., T. Friedrich, O. Elison Timm, M. Chikamoto, A. Abe-Ouchi, and A. Ganopolski (2014) Modeling obliquity and $\mathrm{CO}_{2}$ effects on Southern Hemisphere climate during the past $408 \mathrm{ka}$. J. Climate, 27, 1863-1875.

Toggweiler, J. R. (2008), Origin of the 100,000-year timescale in Antarctic temperatures and atmospheric $\mathrm{CO}_{2}, \quad$ Paleoceanogr., 23(2) doi:10.1029/2006PA001405.

Torrence, C. and G. P. Compo, 1998: A Practical Guide to Wavelet Analysis. Bull. Amer. Meteor. Soc., 79, 61-78.

Tziperman, E. \& Gildor, H. 2003. On the mid-Pleistocene transition to $100 \mathrm{kyr}$ glacial cycle and the asymmetry between glaciation and deglaciation times. Paleoceanography 18, 1, 1001, DOI: 10.1029/2001PA000627.

Woodroffe, C.D. and J. M.Webster, 2014. Coral reefs and sea-level change, Marine Geology 352, 248-267.

Zachos, J.C., Pagani, M., Sloan, L., Thomas, E. \& Billups, K. 2001. Trends, rhythms and aberrations in global climate $65 \mathrm{Ma}$ to present. Science 292, 686-693. 